\title{
New Insights into the Antimicrobial Action of Cinnamaldehyde towards Escherichia coli and Its Effects on Intestinal Colonization of Mice
}

\author{
Wellison A. Pereira ${ }^{1}$ D , Carlos Drielson S. Pereira ${ }^{1}$, Raíssa G. Assunção ${ }^{1,2}$, Iandeyara Savanna C. da Silva ${ }^{1,2}$, \\ Fabrícia S. Rego ${ }^{1}$, Leylane S. R. Alves ${ }^{1}$, Juliana S. Santos ${ }^{1}$, Francisco Jonathas R. Nogueira ${ }^{1,2}$, \\ Adrielle Zagmignan ${ }^{1}$, Thomas T. Thomsen ${ }^{3}{ }^{(D}$, Anders Lobner-Olesen ${ }^{3}$, , Karen A. Krogfelt ${ }^{4}$, \\ Luís Cláudio N. da Silva ${ }^{1}$ (D) and Afonso G. Abreu ${ }^{1,2, *(\mathbb{D})}$
}

check for updates

Citation: Pereira, W.A.; Pereira, C.D.S.; Assunção, R.G.; da Silva, I.S.C.; Rego, F.S.; Alves, L.S.R.; Santos, J.S.; Nogueira, F.J.R.; Zagmignan, A.; Thomsen, T.T.; et al. New Insights into the Antimicrobial Action of Cinnamaldehyde towards Escherichia coli and Its Effects on Intestinal Colonization of Mice. Biomolecules 2021, 11, 302. https:// doi.org/10.3390/biom11020302

Academic Editor: Hani S. El-Nezami Received: 15 January 2021

Accepted: 10 February 2021

Published: 18 February 2021

Publisher's Note: MDPI stays neutral with regard to jurisdictional claims in published maps and institutional affiliations.

Copyright: (c) 2021 by the authors. Licensee MDPI, Basel, Switzerland. This article is an open access article distributed under the terms and conditions of the Creative Commons Attribution (CC BY) license (https:/ / creativecommons.org/licenses/by/ $4.0 /)$.
1 Laboratório de Patogenicidade Microbiana, Programa de Pós-Graduação em Biologia Microbiana, Universidade Ceuma, São Luís 65075-120, Brazil; well.ap@usp.br (W.A.P.); drielsonn.sousa@gmail.com (C.D.S.P.); raissa_guara@hotmail.com (R.G.A.); savannacarsi@gmail.com (I.S.C.d.S.); fabricia_sr@hotmail.com.br (F.S.R.); leylanesusy@hotmail.com (L.S.R.A.); julianass98@hotmail.com (J.S.S.); frjonathas@outlook.com (F.J.R.N.); adrielle.zagmignan@ceuma.br (A.Z.); luiscn.silva@ceuma.br (L.C.N.d.S.)

2 Programa de Pós-Graduação em Ciências da Saúde, Universidade Federal do Maranhão, São Luís 65080-805, Brazil

3 Department of Functional Genomics, University of Copenhagen, 2200 Copenhagen, Denmark; thomas.thomsen@bio.ku.dk (T.T.T.); lobner@bio.ku.dk (A.L.-O.)

4 Department of Science and Environment, Roskilde University, 4000 Roskilde, Denmark; kak@ssi.dk

* Correspondence: afonso.abreu@ceuma.br

\begin{abstract}
Escherichia coli is responsible for cases of diarrhea around the world, and some studies have shown the benefits of cinnamaldehyde in the treatment of bacterial disease. Therefore, the objective of this study was to evaluate the effects of cinnamaldehyde in mice colonized by pathogenic E. coli, as well as to provide more insights into its antimicrobial action mechanism. After determination of minimum inhibitory (MIC) and minimum bactericidal (MBC) concentrations, the interference of cinnamaldehyde in macromolecular pathways (synthesis of DNA, RNA, protein, and cell wall) was measured by incorporation of radioisotopes. The anti-adhesive properties of cinnamaldehyde towards E. coli 042 were evaluated using human epithelial type 2 (HEp-2) cells. Intestinal colonization was tested on mice, and the effect of cinnamaldehyde on Tenebrio molitor larvae. Cinnamaldehyde showed MIC and MBC values of $780 \mu \mathrm{g} / \mathrm{mL}$ and $1560 \mu \mathrm{g} / \mathrm{mL}$, respectively; reduced the adhesion of E. coli 042 on HEp-2 cells; and affected all the synthetic pathways evaluated, suggesting that compost impairs the membrane/cell wall structure leading bacteria to total collapse. No effect on the expression of genes related to the SOS pathway (sulA and $\operatorname{dinB1}$ ) was observed. The compound did not interfere with cell viability and was not toxic against T. molitor larvae. In addition, cinnamaldehyde-treated mice exhibited lower levels of colonization by E. coli 042 than the untreated group. Therefore, the results show that cinnamaldehyde is effective in treating the pathogenic E. coli strain 042 and confirm it as a promising lead molecule for the development of antimicrobial agents.
\end{abstract}

Keywords: cinnamaldehyde; intestinal colonization; natural products

\section{Introduction}

Escherichia coli is an important pathogen responsible for numerous cases of diarrhea worldwide, representing a serious problem for immunocompromised individuals, and especially children [1-4]. Several reports have associated diarrhea with significant delays in childhood development $[1,3,5]$.

In a study carried out in South America, Africa and Asia, in children and adults with diarrhea, the predominant pathogen isolated in fecal samples was enteroaggregative E. coli 
(EAEC), a pathotype of diarrheagenic E. coli [6,7]. Depending on the region, EAEC can be the etiologic agent of up to $30 \%$ of episodes of diarrhea in infants and young children, as well as in adults with persistent diarrhea [8].

According to the World Health Organization, antibacterial drugs have become less effective or even ineffective, resulting in an accelerating global health security emergency that is rapidly outpacing available treatment options [9]. Therefore, due to the difficult treatment of several diseases of microbial origin, it is important to identify and characterize compounds of natural origin that can be used safely in the treatment of infections. Cinnamaldehyde has been used as a potential alternative for antimicrobial therapy by several in vitro and in vivo studies $[10,11]$. It is a major component found in the essential oil extracted from cinnamon bark (Cinnamomum cassia; Lauraceae), being responsible for the characteristic taste and odor of the species [10,12].

Cinnamaldehyde has shown a wide spectrum of antimicrobial activity by inhibiting pathogens such as Candida spp. [13,14], E. coli [15], Listeria monocytogenes [16], Pseudomonas aeruginosa [17], and Staphylococcus aureus [18]. Most of the studies carried out with this compound are related to the food industry, where it is especially used for its antimicrobial properties [12]. Recently, the oral supplementation with cinnamaldehyde was able to inhibit the colonization of uropathogenic E. coli (UPEC) in lower urinary tract infection in mice [11]. Besides, it is pointed as a promising agent to treat inflammatory disorders $[19,20]$, diabetes [21], and cancer [22,23]. Therefore, the aim of this study was to evaluate the effect of cinnamaldehyde in colonization of mouse gut by pathogenic E. coli, as well as to provide more insights into its antimicrobial action mechanism.

\section{Material and Methods}

\subsection{Bacteria}

E. coli strains were used to evaluate the effect of cinnamaldehyde in this study (Table 1). The strains were kept at $-80{ }^{\circ} \mathrm{C}$ in trypticase soy broth (TSB) plus $20 \%$ glycerol and grown in Luria-Bertani broth (LB), LB agar, or MacConkey, plus appropriate antibiotics when indicated.

Table 1. Escherichia coli strains used in the evaluation of the effect of cinnamaldehyde.

\begin{tabular}{|c|c|c|}
\hline Strain & Description & Reference \\
\hline E. coli 042 & $\begin{array}{l}\text { Standard strain for studies with } \\
\text { enteroaggregative E. coli (EAEC), isolated } \\
\text { from an outbreak of diarrhea in Peru. }\end{array}$ & {$[24]$} \\
\hline E. coli HB101 & $\begin{array}{l}\text { Non-pathogenic strain, used as negative } \\
\text { control of adhesion assays. }\end{array}$ & [25] \\
\hline E. coli MG1655 & $\begin{array}{l}\text { Non-pathogenic wild type strain used as } \\
\text { control in SOS and radioisotope assays. }\end{array}$ & $\begin{array}{l}{[26]} \\
{[27]}\end{array}$ \\
\hline E. coli ALO4696 & MG1655; sulA::lacZ. & This work \\
\hline E. coli ALO562 & GW1010 $\operatorname{din} B 1:: M u d(\mathrm{Ap}, \mathrm{lac})$ & [28] \\
\hline E. coli BW25113 (ALO 4628) & Wild-type strain from Keio Collection & [29] \\
\hline E. coli JW3682 (ALO 3542) & BW25113; $\Delta y i d D:: k a n, \operatorname{Kan}^{\mathrm{R}}$ & [29] \\
\hline E. coli JW3820 (ALO 3544) & BW25113; $\Delta$ fre::kan, $\mathrm{Kan}^{\mathrm{R}}$ & [29] \\
\hline E. coli JW2513 (ALO 3545) & BW25113; $\Delta$ iscU::kan, $\mathrm{Kan}^{\mathrm{R}}$ & [29] \\
\hline E. coli JW3879-1 (ALO 4554) & BW25113; $\Delta$ sodA::kan, $\mathrm{Kan}^{\mathrm{R}}$ & [29] \\
\hline E. coli JW1648-1 (ALO 4555) & BW25113; $\Delta$ sodB::kan, $\operatorname{Kan}^{\mathrm{R}}$ & [29] \\
\hline
\end{tabular}

The reporter strain E. coli ALO 4696 was obtained by P1 transduction using phage lysates of the E. coli ALO4025 (MG1655; sfiA::Km) into E. coli ALO3980 (MG1655; sfiA::lacZ). The transductants were selected using agar plates containing kanamycin $(10 \mu \mathrm{g} / \mathrm{mL})$. The 
expression of sulA can be quantified in the resultant strain (ALO 4696) as it is integrated with $\beta$-galactosidase gene (reporter gene) and the deletion of seqA prevents excessive filamentation. The expression of sulA was tested using various concentrations of ciprofloxacin after different incubation time. $\beta$-galactosidase activities were measured as described by Miller [30].

\subsection{Minimum Inhibitory (MIC) and Minimum Bactericidal Concentration (MBC)}

Overnight cultures of E. coli strains were diluted (1:100) in Mueller Hinton broth (MH) and grown until they reached an optical density of 0.1 at $600 \mathrm{~nm}$. Aliquots of $10 \mu \mathrm{L}$ of this suspension were added to wells containing different concentrations of cinnamaldehyde (ranging from $195 \mu \mathrm{g} / \mathrm{mL}$ to $6240 \mu \mathrm{g} / \mathrm{mL}$ ). Cinnamaldehyde (trans-cinnamaldehyde 99\%) used in this study was obtained from Sigma-Aldrich (Darmstadt, Germany).

After $24 \mathrm{~h}$ incubation at $37^{\circ} \mathrm{C}$, resazurin $0.03 \%$ was used to determine the minimum inhibitory concentration (MIC). Aliquots from those wells without bacterial growth were transferred to MacConkey agar plates to determine the minimum bactericidal concentration (MBC). All assays were performed in triplicate with at least two repetitions [31].

\subsection{Macromolecular Synthesis}

The effects of cinnamaldehyde on the assembly of key bacterial cellular processes was evaluated by testing cinnamaldehyde's effect on macromolecular synthesis: incorporation of radioactive precursors [methyl ${ }^{3} \mathrm{H}$ ] thymidine, uridine, arginine and glucosamine for synthesis of DNA, RNA, protein, and cell wall, respectively (Table 2).

Table 2. Description of the precursors used in the incorporation test of radioactive macromolecules. The effects of cinnamaldehyde on the assembly of the main bacterial structures were evaluated by the incorporation of radioactive precursors thymidine, uridine, arginine, and glucosamine for DNA, RNA, protein, and cell wall synthesis, respectively.

\begin{tabular}{ccccc}
\hline Precursors & Marked Precursor & Function & Time of Incorporation & Antibiotic Control \\
\hline Thymidine & $\mathrm{H}^{3}$-Thymidine & DNA Replication & $4 \mathrm{~min}$ & Nalidixic Acid \\
Uridine & $\mathrm{H}^{3}$-Uridine & RNA Synthesis & $2 \mathrm{~min}$ & Rifampicin \\
Glucosamine & $\mathrm{H}^{3}$-Glucosamine & Cell wall Synthesis & $20 \mathrm{~min}$ & Ampicillin \\
Arginine & $\mathrm{H}^{3}$-Arginine & Protein Synthesis & $4 \mathrm{~min}$ & Chloramphenicol \\
\hline
\end{tabular}

For this, E. coli MG1655 was exponentially grown in minimum medium supplemented with $2.5 \mathrm{mg}$ thiamine $/ \mathrm{mL}$ and $0.5 \%(w / v)$ glucose (ABTG) until it reached an $\mathrm{OD}_{450}$ of 0.1. At $\mathrm{OD}_{450}$ of 0.1 , growing cultures were split into several flasks depending on treatment. The cultures were treated with cinnamaldehyde $(1000 \mu \mathrm{g} / \mathrm{mL})$ or antibiotic (Table 2) after $35 \mathrm{~min}$. Samples $(500 \mu \mathrm{L})$ and $\mathrm{OD}_{450}$ were collected at determined periods $(15,35,50$, $60,80,100$ and $120 \mathrm{~min}$ ). Macromolecular incorporation was measured by addition of $0.375 \mu \mathrm{Ci}$ of each precursor to the $500 \mu \mathrm{L}$ sample. The sample was allowed to grow at $37^{\circ} \mathrm{C}$, according to the specific time of incorporation of each precursor (Table 2). After this period, $5 \mathrm{~mL}$ of $5 \%$ TCA containing $0.1 \mathrm{M} \mathrm{NaCl}$ was used to stop the reaction, followed by the reading of $\mathrm{OD}_{450}$ of the sample culture. The samples were filtered, followed by filter washing (two times) with 5\% TCA. Finally, the filters were packed into scintillation tubes for overnight drying. After this step $5 \mathrm{~mL}$ scintillation fluid (ULTIMA GOLD, PerkinElmer, Waltham, MA, USA) was added to the vials and labeled precursors were quantified using a scintillation counter HIDEX 300 SL (Turku, Finland). Thus, the value obtained by reading the radioactivity in counts per minute $(\mathrm{CPM})$ was divided by the $\mathrm{OD}_{450}$ to account for differences in growth rate in incorporation rate.

\subsection{Evaluation of the Expression of Genes Associated with SOS Response}

The effect of cinnamaldehyde on SOS response was performed using E. coli sulA:: lacZ (ALO 4696) and E. coli dinB1::lacZ (ALO 562) (Table 1). Overnight cultures of both strains were diluted in $\mathrm{LB}$ broth (1:100) and grown until $\mathrm{OD}_{600}$ of 0.1 was reached. Strains 
were incubated with ciprofloxacin as positive control ( $\frac{1}{2}$ MIC and $\frac{1}{4} \mathrm{MIC} ; 0.5 \mu \mathrm{g} / \mathrm{mL}$ and $0.25 \mu \mathrm{g} / \mathrm{mL}$, respectively) and cinnamaldehyde $\left(\frac{1}{2}\right.$ MIC and $\left.\frac{1}{4} \mathrm{MIC}\right)$ at $37^{\circ} \mathrm{C}$ under shaking at $150 \mathrm{rpm}$. After $3 \mathrm{~h}, 500 \mu \mathrm{L}$ of cell suspension were permeabilized with $100 \mu \mathrm{L}$ of Toluene (Merck, Darmstadt, Germany). Following, the supernatant $(100 \mu \mathrm{L})$ was added to $1 \mathrm{~mL}$ of the Zeta buffer containing ONPG (substrate for the enzyme $\beta$-Galactosidase). The tubes were again incubated in a water bath at $30^{\circ} \mathrm{C}$ with shaking, and the time that each sample took until the color change was verified. After color change the reaction was stopped with a solution of sodium bicarbonate followed by reading of OD at $450 \mathrm{~nm}$.

\subsection{Adhesion Test with Human Epithelial Type 2 (Hep-2) Cells}

The adherence test was carried out according to the protocol described by Scaletsky et al. [32] with modifications. HEp-2 cells were cultured in $50 \mathrm{~mL}$ bottles (Nunc, Inter Med, Roskilde, Denmark) containing Dulbeco's Modified Minimum Eagle Medium (DMEM) containing antibiotics penicillin $(100 \mathrm{U} / \mathrm{mL})$ and streptomycin $(1 \mathrm{mg} / \mathrm{mL})$ (Cultilab, Campinas, Brazil), plus $10 \%$ fetal bovine serum for $2-3$ days at $37{ }^{\circ} \mathrm{C}$ under an atmosphere of $10 \% \mathrm{O}_{2}$ and $90 \% \mathrm{CO}_{2}$. After this incubation period, cells were transferred to Nunc 24-well plates (Merck, Darmstadt, Germany) containing glass coverslips and incubated under the same conditions until reaching $75 \%$ confluence.

E. coli 042 was cultured in $3 \mathrm{~mL}$ of LB without shaking at $37^{\circ} \mathrm{C}$ for $18 \mathrm{~h}$, and aliquots of $20 \mu \mathrm{L}$ of bacterial cultures were added to each well of the plate containing HEp-2 cells. Following $3 \mathrm{~h}$ of incubation, cinnamaldehyde $(600 \mu \mathrm{g} / \mathrm{mL})$ was added to each well. After washing and fixation steps with methanol, cells were stained with methylene blue eosin dye in May-Grünwald solution (Merck, Darmstadt, Germany) and azur-eosin-methylene blue dye solution according to Giemsa (Merck). After washing for removal of excess dye, the coverslips were dried at room temperature and mounted on slides for Entellan (Merck) microscopy. Then, the slides were analyzed by light microscopy.

\subsection{Cytotoxicity Assay}

The assay is based on the extent of the damage induced by the compound. It is used to determine cell viability by quantifying the MTT (3-(4,5-dimethylthiazol-2-yl)-2,5diphenyltetrazolium bromide) present in the medium reduced by the cellular metabolic activity bound to NADH forming blue formazan crystals [33].

To evaluate a possible cytotoxic effect of cinnamaldehyde, the compound at various concentrations (from $100 \mu \mathrm{g} / \mathrm{mL}$ to $12,000 \mu \mathrm{g} / \mathrm{mL}$ ) was incubated with Vero or Hep-2 cells for a period of $48 \mathrm{~h}$. After the incubation period, $100 \mu \mathrm{L}$ of MTT was added to each well and the plates incubated for $3 \mathrm{~h}$ at $37{ }^{\circ} \mathrm{C}$ and $5 \% \mathrm{CO}_{2}$. Then, $100 \mu \mathrm{L}$ of dimethylsulfoxide (DMSO) was added and the samples were homogenized for complete dissolution of the formazan crystals, before measuring absorbance at $550 \mathrm{~nm}$.

\subsection{Effect of Cinnamaldehyde on Tenebrio molitor Larvae}

The objective of this step was to evaluate a possible toxic effect of the compound on $T$. molitor larvae prior to animal testing. Therefore, larvae were randomly selected $(\sim 200 \mathrm{mg})$ for toxicity tests ( $n=10$ /group). In the survival test, one group of lavas was inoculated with $10 \mu \mathrm{L}$ of phosphate buffered saline (PBS) and another with $10 \mu \mathrm{L}$ of cinnamaldehyde at a concentration corresponding to $10 \times \mathrm{MIC}$. After inoculation, the larvae were incubated at $37^{\circ} \mathrm{C}$ and the mortality rate was observed for 7 days. Kaplan-Meier curve and the long-rank test were used for the survival analysis [34].

\subsection{Mouse Colonization}

We performed animal studies on female swiss mice obtained from the Central Animal House of the Ceuma University (São Luís, Brazil). The mice were ten to twelve weeks old, average body weight $\sim 25 \mathrm{~g}$ and maintained at $26 \pm 2{ }^{\circ} \mathrm{C}, 44 \%$ to $56 \%$ relative humidity, under $12 \mathrm{~h}$ light-dark cycles, and maintained with free access to sterile food and acidified water. Bacterial inoculation was performed by gavage described below. All proce- 
dures were assessed and approved by the Committee of Ethics in Research of the Ceuma University (Process $n^{\circ}$ 229/17).

The animals were separated into four groups with six animals each: PBS; animals infected with E. coli 042; animals infected with E. coli 042 and treated with cinnamaldehyde $20 \mathrm{mg} / \mathrm{kg}$; and animals infected with E. coli 042 and treated with cinnamaldehyde $40 \mathrm{mg} / \mathrm{kg}$.

The streptomycin-treated mouse model [35] was used to investigate the intestinal colonization by EAEC 042, as well as the treatment with $200 \mu \mathrm{L}$ daily of cinnamaldehyde ( 20 or $40 \mathrm{mg} / \mathrm{kg}$ ) by gavage, after the colonization.

Initially, Swiss mice provided ad libitum with drinking water containing $5 \mathrm{~g} /$ liter of streptomycin from $48 \mathrm{~h}$ prior to the inoculation and for the duration of the experiment were used. Bacterial suspensions of EAEC 042 were prepared at a final concentration of $5 \times 10^{3} \mathrm{CFU} / \mathrm{mL}$ and $200 \mu \mathrm{L}$ of these suspensions was administered orogastrically by gavage. Fresh fecal samples were collected in sterile tubes, weighted, diluted, and homogenized in sterile PBS. Serial dilutions of these preparations $\left(1: 10^{1}\right.$ until 1:10 $)$ were then plated onto MacConkey agar containing streptomycin $(100 \mu \mathrm{g} / \mathrm{mL})$ for determination of CFU/g. Bacteria were quantified by plate counts for 15 consecutive days post infection. PCR for detection of pic (virulence marker) was also performed to confirm intestinal colonization. Primer sequences, amplified product size, and annealing temperature for pic is described by Abreu et al. [36].

\subsection{Statistical Analysis}

Statistical analyzes were performed using Graph Pad Prism software, version 7.0. The results were expressed as mean and standard deviation and were subjected to ANOVA, followed by the multiple comparisons test from Tukey's test, T-test or Kruskal-Wallis, and Mann-Whitney tests when the data normality assumption was not satisfied. The Kaplan-Meier curve and the long-rank test $(p<0.05)$ were used for survival analysis.

\section{Results}

\subsection{Cinnamaldehyde Inhibits E. coli Growth}

The first step of this research was to evaluate the antimicrobial action of cinnamaldehyde against $E$. coli strains. The compound showed MIC ranging from 780 to $3120 \mu \mathrm{g} / \mathrm{mL}$ among the strains (Table 3). For both E. coli 042 (reference prototype for intestinal colonization studies) and HB101 (non-pathogenic), the MIC and MBC values were 780 and $1560 \mu \mathrm{g} / \mathrm{mL}$, respectively. The strain E. coli MG1655 was killed by cinnamaldehyde at $390 \mu \mathrm{g} / \mathrm{mL}$.

Table 3. Minimum Inhibitory Concentration and Minimum Bactericidal Concentration using cinnamaldehyde.

\begin{tabular}{ccc}
\hline E. coli Strain & MIC $(\mu \mathrm{g} / \mathrm{mL})$ & MBC $(\mu \mathrm{g} / \mathrm{mL})$ \\
\hline 042 & 780 & 1560 \\
HB101 & 780 & 1560 \\
4628 & 1560 & 1560 \\
3542 & 780 & 3120 \\
3544 & 780 & 780 \\
3545 & 780 & 3120 \\
4554 & 3120 & 3120 \\
4555 & 3120 & 3120 \\
\hline
\end{tabular}

We also evaluated the antimicrobial effect of cinnamaldehyde in a strain derived from E. coli BW25113 (E. coli ALO 4628). However, we did not observe significant changes on MIC values for cinnamaldehyde towards these strains in relation to the wild type (Table 3). 


\subsection{Cinnamaldehyde Interferes in the Macromolecular Synthesis in E. coli}

In order to provide more insights into cinnamaldehyde's effects we assessed the interference of cinnamaldehyde in the synthesis of DNA, RNA, protein and glucosamine (a component of cell wall) in E. coli. As observed in Figure 1, after the addition of cinnamaldehyde, all pathways were impaired.

Thymidine Incorporation $\mathrm{OD}_{450}$

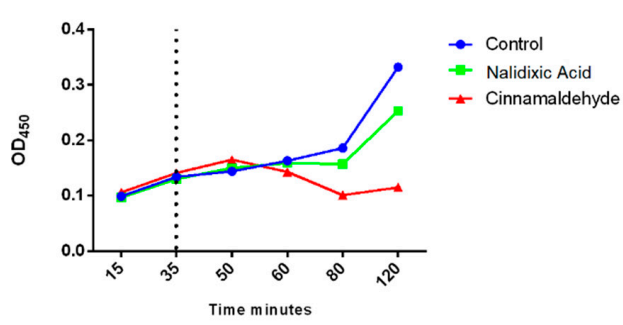

Uridine Incorporation $\mathrm{OD}_{450}$
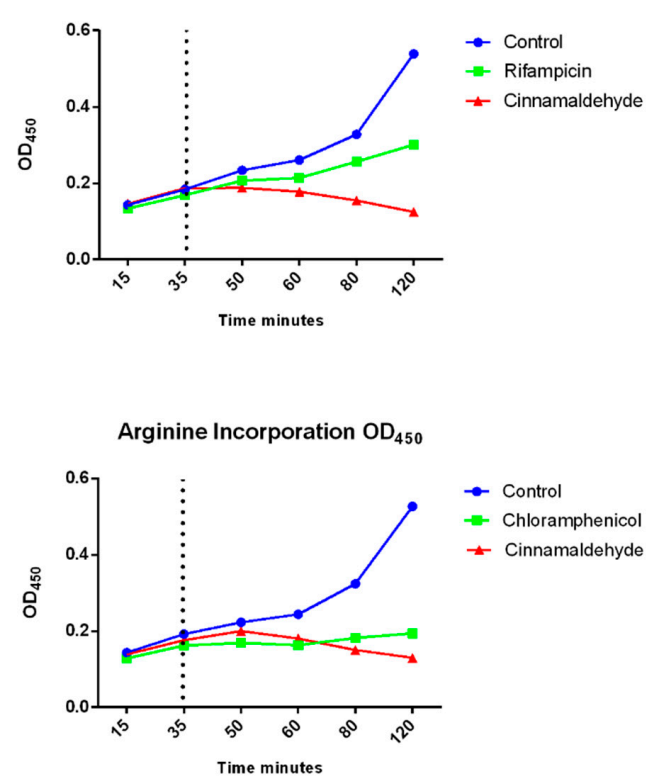

Glucosamine Incorporation $\mathrm{OD}_{450}$

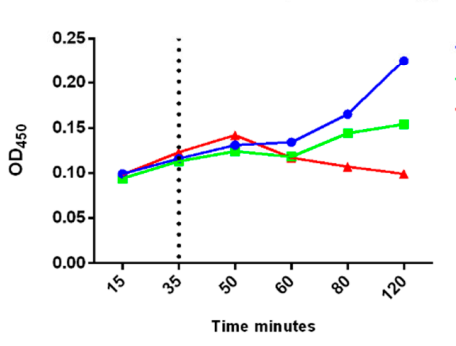

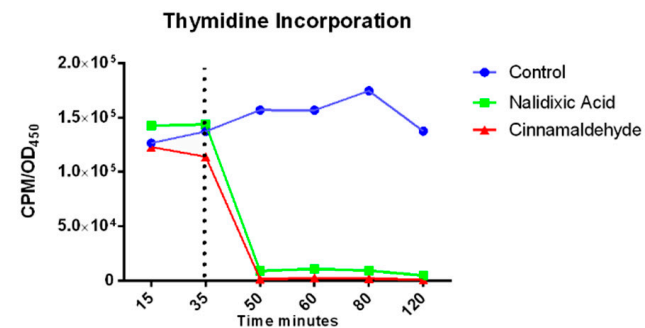
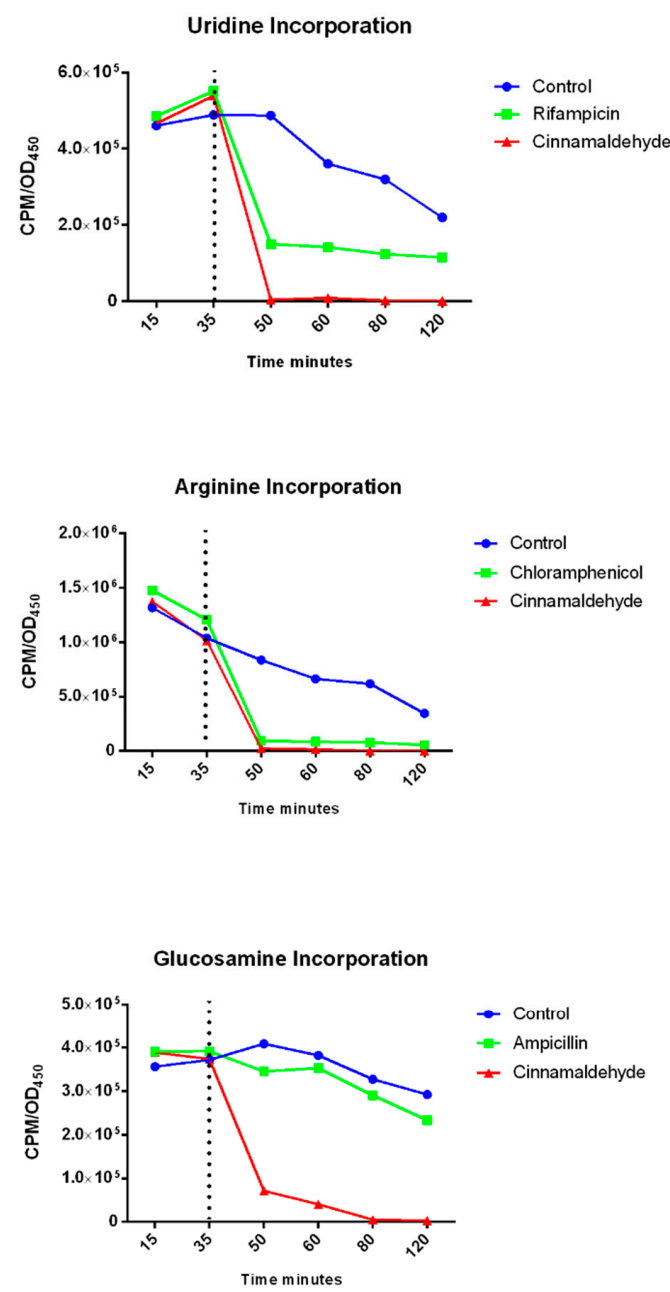

Figure 1. Effects of cinnamaldehyde on the assembly of the main bacterial structures by incorporating the radioactive precursors thymidine, uridine, arginine, and glucosamine that are essential for the synthesis of DNA, RNA, proteins, and cell wall, respectively. The cultures were treated with cinnamaldehyde or antibiotic after $35 \mathrm{~min}$. The samples were collected at determined periods $(15,35,50,60,80,100$, and $120 \mathrm{~min})$ and transferred to a tube containing $0.375 \mu \mathrm{Ci}$ of each precursor. The sample was allowed to stand, according to the specific time of incorporation of each precursor. Thus, the value obtained by reading the radioactivity was subtracted from the value generated by the O.D., and determined the final result of the incorporation. 
Since cinnamaldehyde blocked DNA synthesis, we evaluated whether cinnamaldehyde treatment is related to the activation of SOS response. For this purpose, two strains of E. coli with SOS-related genes fused with lacZ (ALO4696 sulA::lacZ and ALO562 dinB1::lacZ) were used (Table 1). As expected, the expression of both genes was upregulated by ciprofloxacin (positive control) (Figure 2). However, cinnamaldehyde did not induce the expression of these genes, suggesting that this compound did not directly inhibit DNA replication. In this sense, the blockage in DNA synthesis is expected to be a secondary effect of cinnamaldehyde, possibly by disrupting cellular homeostasis by action on the cell membrane.
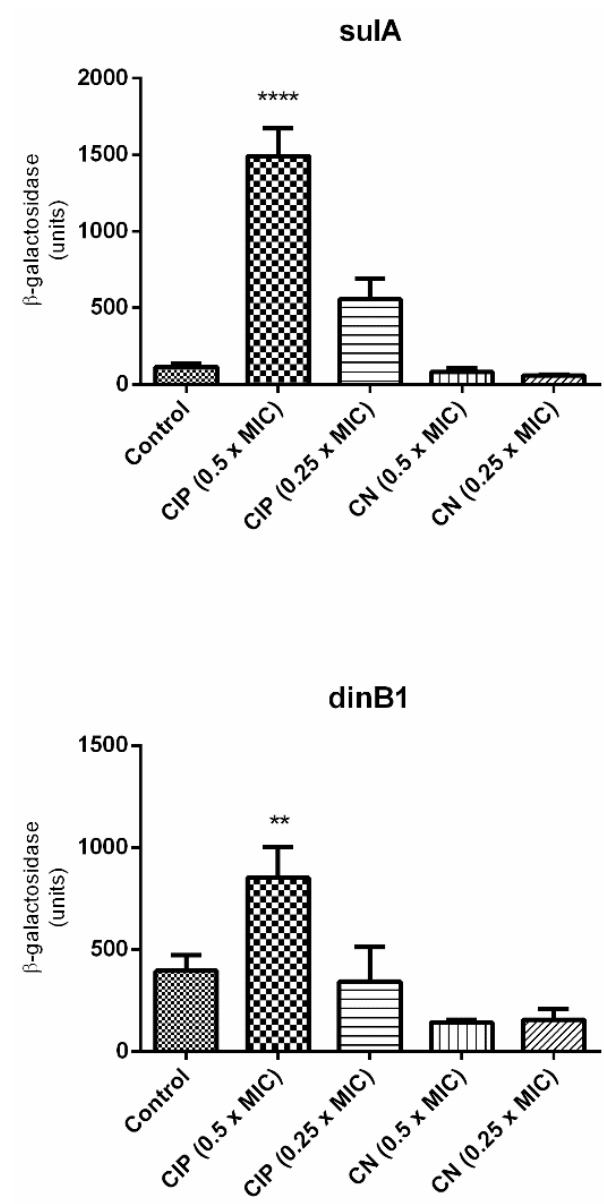

Figure 2. Expression of $s u l A$ and dinB1, genes linked to the SOS response. The test was performed using E. coli sulA::lacZ (ALO 4696) and E. coli dinB1::lacZ (ALO 562). The strains were grown in LB broth until $\mathrm{OD}_{600}$ of 0.1 was reached. Strains were incubated with ciprofloxacin as positive control and cinnamaldehyde. Then the supernatant was added to $1 \mathrm{~mL}$ of Zeta buffer containing ONPG (substrate for the enzyme $\beta$-Galactosidase). The tubes were again incubated in a $30{ }^{\circ} \mathrm{C}$ water bath with shaking and the time taken for each sample until the color change was verified. ${ }^{* * * *} p<0.0001$ when compared to the other groups. ${ }^{* *} p<0.001$ when compared to the other groups.

\subsection{Cinnamaldehyde Does Not Interfere with Cell Viability and Is Not Toxic against T. molitor Larvae}

In order to assess whether cinnamaldehyde would be viable for the in vivo tests, we analyzed its toxic potential towards VERO and Hep-2 cells. After $48 \mathrm{~h}$ of incubation, the substance did not induce significant differences on cell viability (Figure 3). Similarly, cinnamaldehyde did not show toxicity towards T. molitor larvae (Figure 4). 
48 hours/HEp- 2

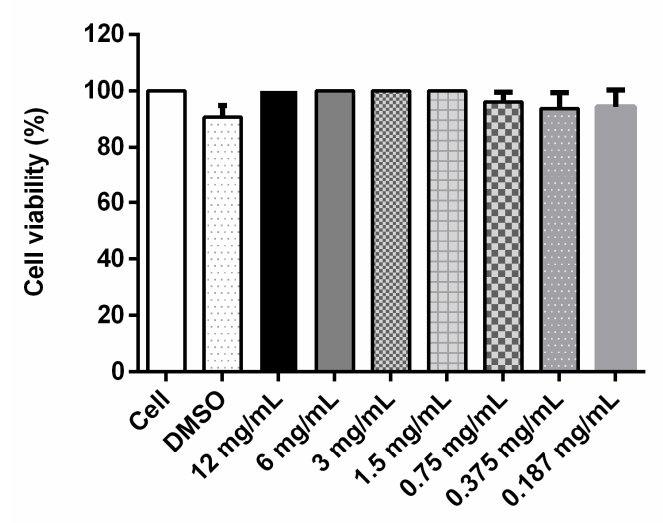

48 hours/ VERO

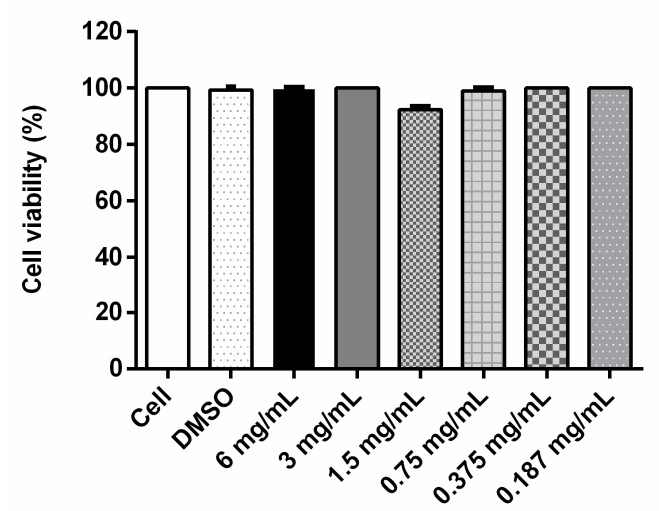

Figure 3. Cell viability assay (MTT) with Vero and HEp-2 cells incubated with cinnamaldehyde at different concentrations for $48 \mathrm{~h}$. To evaluate a possible cytotoxic effect of cinnamaldehyde, the compound at various concentrations was incubated with VERO or Hep-2 cells for $48 \mathrm{~h}$. Then $100 \mu \mathrm{L}$ MTT (3- (4,5-dimethylthiazol-2-yl) -2,5-diphenyltetrazolium bromide) was added to each well and the plates were incubated for $3 \mathrm{~h}\left(37^{\circ} \mathrm{C}\right.$ and $\left.5 \% \mathrm{CO}_{2}\right)$; after, $2 \mu \mathrm{L}$ of dimethyl sulfoxide (DMSO) was added. The contents of each well were subjected to absorbance determination at a wavelength of $550 \mathrm{~nm}$.

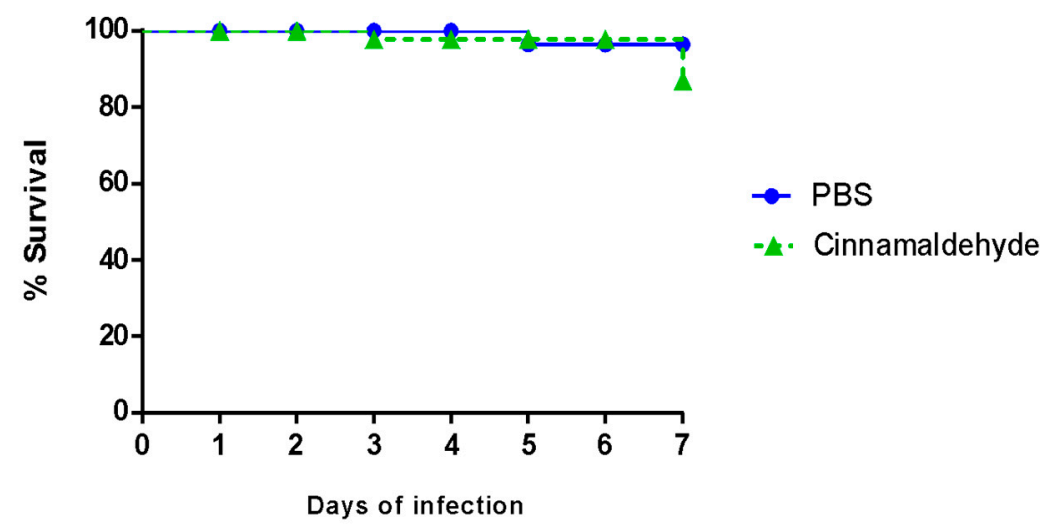

Figure 4. Survival curve with Tenebrio molitor larvae treated with PBS or cinnamaldehyde. Larvae ( $100 \mathrm{mg}$ ) were randomly assigned to experimental groups ( $n=10 /$ group), and then treated with injection of $10 \mu \mathrm{L}$ cinnamaldehyde or PBS. After injections, the larvae were incubated at $37^{\circ} \mathrm{C}$ and the mortality rate was observed for seven days after infection. 


\subsection{Cinnamaldehyde Promotes Reduction of EAEC 042 Aggregative Adhesion on HEp-2 Cells}

It was verified whether cinnamaldehyde was able to inhibit the adhesion of the EAEC 042 strain onto HEp-2 cells (Figure 5). It was possible to observe that the compound was able to inhibit the adhesion of strain 042 after $3 \mathrm{~h}$ at a concentration of $600 \mu \mathrm{g} / \mathrm{mL}$. As can be seen in Figure 5, when comparing the adhesion pattern of EAEC 042 and EAEC $042+$ treatment with cinnamaldehyde, it can be noted the substance's anti-adhesion effect on the strain tested.
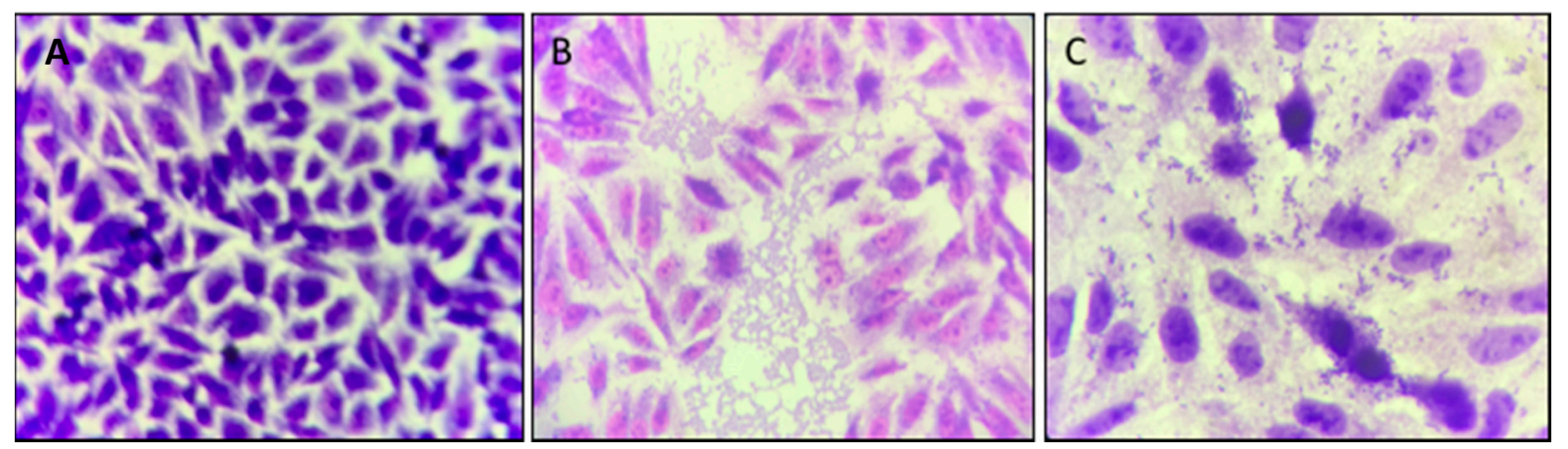

Figure 5. E. coli 042 adhesion test on HEp-2 cells exposed to cinnamaldehyde $(600 \mu \mathrm{g} / \mathrm{mL})$. The cells were stained with May-Grünwald / Giemsa solution and visualized by 1,000-fold light microscopy. (A) HEp-2 cell control, (B) EAEC 042 strain aggregate adhesion pattern, (C) strain 042 adhesion pattern after cinnamaldehyde treatment $(600 \mu \mathrm{g} / \mathrm{mL})$.

\subsection{Cinnamaldehyde Treatment Reduced the Intestinal Colonization of Mice by E. coli}

The ability of EAEC 042 to colonize the intestine mucosa was evaluated using the streptomycin-treated mouse model. The strain was able to colonize mice on the second day post infection and up to the fifteenth day, with a peak of colonization observed on the eighth day. From the eighth to the fourteenth day, colonization declined, probably in response to immune system action (Figure 6).

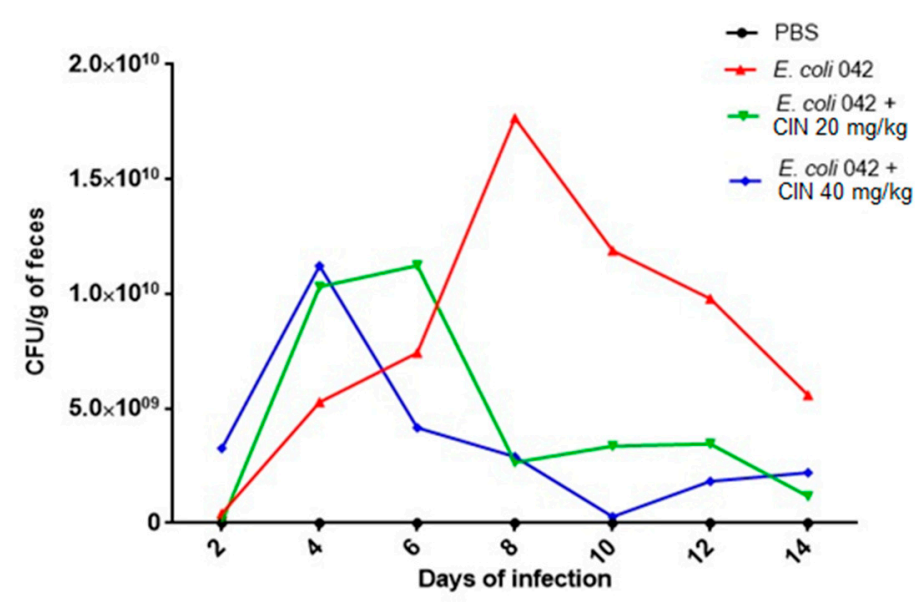

Figure 6. Colony forming units isolated from feces from animals colonized by EAEC 042 and treated with cinnamaldehyde. Suspensions of E. coli strain 042 were prepared to a final concentration of $5 \times 10^{3} \mathrm{CFU} / \mathrm{mL}$. The inoculum $(200 \mu \mathrm{L})$ was administered orally, and fresh feces were collected daily up to 15 days after infection. Feces were weighed, homogenized in $1 x$ sterile PBS (pH 7.4), and serial dilutions were seeded in MacConkey Agar containing streptomycin $(100 \mu \mathrm{g} / \mathrm{mL})$ for CFU counting.

Testing two different cinnamaldehyde concentrations, we showed that the group receiving daily doses of cinnamaldehyde $40 \mathrm{mg} / \mathrm{kg}$ presented a decrease in the colonization on the fourth day, unlike the untreated group. The group treated with cinnamaldehyde 
$20 \mathrm{mg} / \mathrm{kg}$ also showed a significant reduction after the sixth day when compared to the untreated group. From the eighth to the last day, the decrease in the count of the microorganisms remained with slight variation in both groups (20 and $40 \mathrm{mg} / \mathrm{kg}$ ) (Figure 6).

\section{Discussion}

In this study, we analyzed the antimicrobial activity of cinnamaldehyde against $E$. coli strains and provided new insights into its antimicrobial action mechanism. We showed that cinnamaldehyde was able to inhibit $E$. coli growth, conforming previous studies. He et al. [15] evaluated the action of cinnamaldehyde on E. coli, showing that it has an inhibitory effect on the growth. Wang et al. [10] evaluated cinnamaldehyde on the biofilm formation of Porphyromonas gingivalis. The authors report that the compound inhibits formation of biofilm even at sub inhibitory concentrations.

We also assessed cinnamaldehyde toxicity on epithelial cells and in T. molitor larvae. The experiment showed that cinnamaldehyde was non-toxic to Hep-2 and VERO cells, nor was it detrimental to T. molitor larvae. Similarly, Ferro et al. [18] emphasized not only the antimicrobial power of the compound, but also brought new data about its protective character in a Galleria mellonella larvae model, widely used in toxicity tests. In addition, the authors showed that cinnamaldehyde presented a bactericidal action against Staphylococcus aureus and multi-resistant Enterococcus faecalis, as well as increased larval survival and reduced the amount of $S$. aureus isolated in larval hemolymph.

After the toxicity assays, we evaluated whether cinnamaldehyde treatment could be related to activation of SOS response. Superoxide dismutase (SOD) has been associated with defense against reactive oxygen species and bacterial resistance to damage caused by antimicrobial substances [15]. In this study, E. coli strains $4554(\operatorname{sod} A)$ and $4555(\operatorname{sodB})$ were exposed to stress conditions promoted by exposure to cinnamaldehyde. We could not confirm the results by $\mathrm{He}$ et al. [15], which correlates the superoxide dismutase genes with the action of cinnamaldehyde. For the authors, the total SOD action of the E. coli strain tested is proportional to the increase in cinnamaldehyde concentration, indicating that the compound may lead to oxidative damage of the cell membrane and also to SOD activity, which would lead to a more effective response and, consequently, resistance, especially in the antioxidant gene SOD.

When we analyzed the SOS response using sulA and $\operatorname{din} B 1$ genes, the data indicated that there was a low expression of these genes, showing that cinnamaldehyde interferes in the bacteria growth and causes death without necessarily inducing an SOS.

The $\operatorname{din} B$ gene was first described in 1980 as part of the DNA damage response. It was shown to be induced by exposure to UV radiation [37]. According to Ordonez et al. [38], $\operatorname{din} B$ (also called DNA Polymerase IV) has its transcription controlled by lexA, when there is damage to the genetic material. It has also been associated with repetitive sequence replication and mutation [39]. Suttom et al. [40], when reviewing the aspects related to SOS response, affirmed that $\operatorname{din} B$ would not be associated to repairs for damages caused by UV radiation, but to tolerance to other types of DNA damage.

Furthermore, about 30 genes linked to $E$. coli SOS response are induced after damage to bacterial DNA, among which, sulA is one of the most important [40]. The expression of sulA is an indication of stress, since it increases after DNA damage, and may serve as a basis for studies aimed at evaluating the mode of action of antimicrobial candidates. Moreover, the sulA product acts to prevent cell division when it is not in favorable conditions [41].

However, once it was known that cinnamaldehyde did not induce an SOS response by any of the two routes analyzed, it was necessary to evaluate the site of action of the compound. For this, several tests using radioisotopes were performed to evaluate the macromolecular incorporation of precursors for the assembly of essential structures of the bacteria. It was observed that cinnamaldehyde prevented incorporation of the four precursors evaluated. It is noteworthy that the compound had a faster effect by preventing the incorporation of glucosamine and consequently, no cell wall formation. 
The action of cinnamaldehyde on the cell membrane has previously been described in the literature. Wang et al. [10], after analyzing the effect of the substance on the biofilm formed by $P$. gingivalis, investigated the morphological changes, cell membrane damage and DNA, RNA, and protein breakdown. The authors also affirmed that increasing the dose caused greater damage, the morphological changes were irreversible and caused loss of membrane integrity. Furthermore, RNA and DNA synthesis were inhibited. Likewise, He et al. [15] tested the inhibitory effect, oxidative, and membrane damage caused by cinnamaldehyde on E. coli ATCC 25922. By use of Raman spectroscopy the authors showed that the compound had a negative impact on the wall by causing loss of cellular constituents.

In addition to cell damage, a possible interference with the pathogen's ability to adhere is an important assessment that needs to be made. Thus, cell tests are used for a variety of purposes in research laboratories, such as diagnosing, classifying, and identifying $E$. coli adhesion patterns, for example. Among the different pathotypes, EAEC 042 is one of the most studied for its pathogenicity. Most of these studies differentiate EAEC 042 from the other E. coli pathotypes by tests with HEp-2 cells. It is known that it has, as its main characteristic, the high adhesion capacity, attributed to its virulence factors, mainly fimbriae and other aggregative proteins [5].

It is important to note that E. coli 042 adhesion characteristics are standard for EAEC pathotype identification. Jensen et al. [5] described it as having an aggregative adhesion character, binding both to the cell and to other bacteria. Didactically, this form of adhesion is compared to "stacked bricks" and leads to the formation of biofilm, an important structure for maintaining pathogen reservoirs and infection progress.

Here, we demonstrated that cinnamaldehyde was able to reduce EAEC 042 aggregative adhesion on HEp-2 cells. This finding corroborates what was described by Ferro et al. [18], in which cinnamaldehyde reduced the adhesion of S. aureus. Likewise, Prabuseenivasan and colleagues [42], when analyzing the in vitro effect of several essential oils, demonstrated that most of them had antibacterial action against E. coli. Similarly, in a recent study by Li et al. [43], the antimicrobial action of cinnamaldehyde was demonstrated. The authors emphasized the potency of the compound primarily against $S$. aureus ATCC25923, Bacillus subtilis ATCC 9372, E. coli ATCC 25922, and Pseudomonas aeruginosa ATCC 27853.

Since cinnamaldehyde inhibited growth of several E. coli strains and interfered in the macromolecular synthesis, as well as promoted a reduction of EAEC 042 aggregative adhesion on HEp-2 cells, we investigated whether the compound also had the ability to reduce mouse intestinal colonization by EAEC 042.

Swiss mice were infected with EAEC 042 and after establishment of colonization, groups of animals were treated daily by gavage with the compound at two different concentrations in order to verify the action of cinnamaldehyde. At the end of the 15 days of colonization, both groups treated daily with cinnamaldehyde (20 and $40 \mathrm{mg} / \mathrm{kg}$ ) were able to reduce colonization drastically as early as the sixth and eighth day, respectively, leading to the number of CFUs close to zero on the last day, in this way, showing a better performance against the strain of E. coli tested.

Other research has also demonstrated the antimicrobial action of cinnamaldehyde over E. coli. Narayanan et al. [11] in vivo study evaluated oral oil treatment in C57BL mice with urinary tract infection. At the end of the experiment, it was possible to affirm that the treatment reduced colonization of the bacterium in the bladder and urethra and that it was not toxic to the animals.

In a recent study, Yuan and Yuk [44] evaluated the possible interference of some essential oils on the virulence of E. coli O157:H7, an important cause of gastrointestinal infection, in non-lethal concentrations. They demonstrated that the use of cinnamaldehyde led to the temporary suppression of motility, reduced biofilm-forming ability and did not provoke the resistance of $E$. coli strain tested. The authors emphasized that this 
result indicates that the compound can be used for its antimicrobial properties in the food industry.

Malheiro et al. [45] evaluated cinnamaldehyde on three important pathogens, E. coli NCTC (MIC $3 \mathrm{mM}$ ), S. aureus, and Enterococcus hirae, comparing their results with those of biocides; as in the present study, the researchers found that there was a reduction in microbial growth and that cinnamaldehyde was able to inhibit E. coli NCTC at low concentrations. In turn, Yuan et al. [44] decided to investigate the possible interference of natural compounds on bacterial growth using the Time-Kill method, thus it was observed that cinnamaldehyde has good antimicrobial action, especially when combined with eugenol, another component of cinnamon essential oil; the damage they caused to the membrane was considered the main cause.

Firmino and colleagues [46] evaluated the antimicrobial power of the compound on biofilm, a microbial structure important for disease establishment and bacterial protection. According to the authors, cinnamaldehyde was able to inhibit biofilm formation, both in Gram-positive and Gram-negative bacteria, such as E. coli. On the other hand, Field et al. [47] examined the antimicrobial potential of cinnamaldehyde together with another natural compound, bacteriocin Nisin, in a solution with ethylenediaminetetraacetic acid (EDTA) against enterotoxigenic E. coli. At the end of the experiments, it was found that the combination increased the observed antimicrobial potential compared to the results found in the tests with any of the compounds alone.

Taken together our data point to an important role of cinnamaldehyde as inhibitor of the growth of the pathogenic strain EAEC 042 in vitro and in vivo tests. The compound was not toxic to T. molitor larvae or Hep-2 and Vero cells, and reduced the adhesion of the bacterium on HEp-2 cells. In addition, it was possible to show that the compound interfered in the incorporation of key molecules for the assembly of essential structures to the bacterium. Finally, intestinal colonization of mice by EAEC 042 was reduced with cinnamaldehyde treatment ( 20 and $40 \mathrm{mg} / \mathrm{kg}$ ). Such results show that the compound is effective in the treatment against the pathogenic strain 042 and a promising candidate for the development of novel antibacterial drugs.

Author Contributions: Conceptualization, W.A.P. and A.G.A.; methodology, W.A.P., R.G.A. and A.G.A.; formal analysis, L.C.N.d.S., T.T.T., A.L.-O., K.A.K. and A.G.A.; investigation, W.A.P., C.D.S.P., R.G.A., I.S.C.d.S., F.S.R., L.S.R.A., J.S.S., F.J.R.N. and A.Z.; resources, A.L.-O., K.A.K. and A.G.A.; data curation, W.A.P.; L.C.N.d.S., T.T.T., A.L.-O., K.A.K. and A.G.A.; writing-original draft preparation, W.A.P.; writing-review and editing, W.A.P., L.C.N.d.S. and A.G.A.; project administration, A.G.A.; funding acquisition, A.G.A. All authors have read and agreed to the published version of the manuscript.

Funding: This research was funded by the Fundação de Amparo à Pesquisa e ao Desenvolvimento Científico e Tecnológico do Maranhão (FAPEMA), Grants: Universal No. 01278/17, PPSUS No. 05977/16 and BEPP No. 02499/18)

Institutional Review Board Statement: The study was conducted according to the guidelines of the Declaration of Helsinki, and approved by the Committee of Ethics in Research of the Ceuma University (Process n $\left.{ }^{\circ} 229 / 17\right)$.

Informed Consent Statement: Not applicable.

Data Availability Statement: No new data were created or analyzed in this study. Data sharing is not applicable to this article.

Acknowledgments: We thank the Universidade Ceuma for technical and financial support.

Conflicts of Interest: All authors: No reported conflicts.

\section{References}

1. Taghadosi, R.; Shakibaie, M.R.; Hosseini-Nave, H. Antibiotic resistance, ESBL genes, integrons, phylogenetic groups and MLVA profiles of Escherichia coli pathotypes isolated from patients with diarrhea and farm animals in south-east of Iran. Comp. Immunol. Microbiol. Infect. Dis. 2019, 63, 117-126. [CrossRef] [PubMed] 
2. Tharwat, N.; El-Sherif, R.; Elnagdy, S.; Marzaban, R.; Amer, S. Virulent Escherichia coli strains among Egyptian patients with acute diarrhoea versus urinary tract infection, and their antibiotic susceptibility. Arab J. Gastroenterol. 2019, 20, 74-80. [CrossRef] [PubMed]

3. Verma, S.; Venkatesh, V.; Kumar, R.; Kashyap, S.; Kumar, M.; Maurya, A.K.; Singh, M. Etiological agents of diarrhea in hospitalized pediatric patients with special emphasis on diarrheagenic Escherichia coli in North India. J. Lab. Phys. 2019, 11, 68. [CrossRef]

4. Rasko, D.A.; Webster, D.R.; Sahl, J.W.; Bashir, A.; Boisen, N.; Scheutz, F.; Paxinos, E.E.; Sebra, R.; Chin, C.S. Origins of the E. coli strain causing an outbreak of hemolytic-uremic syndrome in Germany. Nejm 2011, 365, 709-717. [CrossRef] [PubMed]

5. Jensen, B.H.; Olsen, K.E.; Struve, C.; Krogfelt, K.A.; Petersen, A.M. Epidemiology and clinical manifestations of enteroaggregative Escherichia coli. Clin. Microbiol. Rev. 2014, 27, 614-630. [CrossRef]

6. Aijuka, M.; Santiago, A.E.; Girón, J.A.; Nataro, J.P.; Buys, E.M. Enteroaggregative Escherichia coli is the predominant diarrheagenic E. coli pathotype among irrigation water and food sources in South Africa. Int. J. Food Microbiol. 2018, 278, 44-51. [CrossRef] [PubMed]

7. Platts-Mills, J.A.; Babji, S.; Bodhidatta, L.; Gratz, J.; Haque, R.; Havt, A.; McCormick, B.J.; McGrath, M.; Olortegui, M.P.; Samie, A.; et al. MAL-ED Network Investigators. Pathogen-specific burdens of community diarrhoea in developing countries: A multisite birth cohort study (MAL-ED). Lancet Glob. Health 2015, 3, e564-e575. [CrossRef]

8. Bouzari, S.; Dashti, A.; Jafari, A.; Oloomi, M. Immune response against adhesins of enteroaggregative Escherichia coli immunized by three different vaccination strategies (DNA/DNA, Protein/Protein, and DNA/Protein) in mice. Comp. Immunol. Microbiol. Infect. Dis. 2010, 33, 215-225. [CrossRef] [PubMed]

9. World Health Organization (WHO). Antimicrobial Resistance: Global Report on Surveillance; World Health Organization (WHO): Geneva, Switzerland, 2014.

10. Wang, Y.; Zhang, Y.; Shi, Y.Q.; Pan, X.H.; Lu, Y.H.; Cao, P. Antibacterial effects of cinnamon (Cinnamomum zeylanicum) bark essential oil on Porphyromonas gingivalis. Microb. Pathog. 2018, 116, 26-32. [CrossRef]

11. Narayanan, A.; Muyyarikkandy, M.S.; Mooyottu, S.; Venkitanarayanan, K.; Amalaradjou, M. Oral supplementation of transcinnamaldehyde reduces uropathogenic Escherichia coli colonization in a mouse model. Lett. Appl. microbiol. 2017, 64, 192-197. [CrossRef] [PubMed]

12. Sun, Q.; Yang, H.; Tang, P.; Liu, J.; Wang, W.; Li, H. Interactions of cinnamaldehyde and its metabolite cinnamic acid with human serum albumin and interference of other food additives. Food Chem. 2018, 243, 74-81. [CrossRef] [PubMed]

13. Bakhtiari, S.; Jafari, S.; Taheri, J.B.; Kashi, T.S.J.; Namazi, Z.; Iman, M.; Poorberafeyi, M. The Effects of Cinnamaldehyde (Cinnamon Derivatives) and Nystatin on Candida Albicans and Candida Glabrata. Open Access Maced. J. Med. Sci. 2019, 7, 1067. [CrossRef] [PubMed]

14. Khan, S.N.; Khan, S.; Iqbal, J.; Khan, R.; Khan, A.U. Enhanced killing and antibiofilm activity of encapsulated cinnamaldehyde against Candida albicans. Front Microbiol. 2017, 8, 1641. [CrossRef] [PubMed]

15. He, T.F.; Wang, L.H.; Niu, D.B.; Wen, Q.H.; Zeng, X.A. Cinnamaldehyde inhibit Escherichia coli associated with membrane disruption and oxidative damage. Arch. Microbiol. 2018, 201,1-8. [CrossRef]

16. Rogiers, G.; Kebede, B.T.; Van Loey, A.; Michiels, C.W. Membrane fatty acid composition as a determinant of Listeria monocytogenes sensitivity to trans-cinnamaldehyde. Res. Microbiol. 2017, 168, 536-546. [CrossRef]

17. Topa, S.H.; Subramoni, S.; Palombo, E.A.; Kingshott, P.; Rice, S.A.; Blackall, L.L. Cinnamaldehyde disrupts biofilm formation and swarming motility of Pseudomonas aeruginosa. Microbiology 2018, 164, 1087-1097. [CrossRef]

18. Ferro, T.A.; Araújo, J.M.; Pinto, B.L.S.; Santos, J.S.; Souza, E.B.; Silva, B.L.; Monteiro-Neto, V. Cinnamaldehyde Inhibits Staphylococcus aureus Virulence Factors and Protects against Infection in a Galleria mellonella Model. Front. Microbiol. 2016, 7, 2052. [CrossRef]

19. Chao, L.K.; Hua, K.F.; Hsu, H.Y.; Cheng, S.S.; Lin, I.F.; Chen, C.J.; Chang, S.T. Cinnamaldehyde inhibits pro-inflammatory cytokines secretion from monocytes/macrophages through suppression of intracellular signaling. Food Chem. Toxicol. 2015, 46, 220-231. [CrossRef] [PubMed]

20. Mendes, S.J.; Sousa, F.I.; Pereira, D.M.; Ferro, T.A.; Pereira, I.C.; Silva, B.L.; Nascimento, J.L. Cinnamaldehyde modulates LPS-induced systemic inflammatory response syndrome through TRPA1-dependent and independent mechanisms. Int. Immunopharmacol. 2016, 34, 60-70. [CrossRef]

21. Sartorius, T.; Peter, A.; Schulz, N.; Drescher, A.; Bergheim, I.; Machann, J.; Schick, F.; Siegel-Axel, D.; Schürmann, A.; Weigert, C.; et al. Cinnamon extract improves insulin sensitivity in the brain and lowers liver fat in mouse models of obesity. PLoS ONE 2014, 9, e92358. [CrossRef] [PubMed]

22. Kwon, H.K.; Hwang, J.S.; So, J.S.; Lee, C.G.; Sahoo, A.; Ryu, J.H.; Jeon, W.K.; Ko, B.S.; Im, C.R.; Lee, S.H.; et al. Cinnamon extract induces tumor cell death through inhibition of NFkB and AP1. BMC Cancer 2010, 10, 392. [CrossRef]

23. Schoene, N.W.; Kelly, M.A.; Polansky, M.M.; Anderson, R.A. Water-soluble polymeric polyphenols from cinnamon inhibit proliferation and alter cell cycle distribution patterns of hematologic tumor cell lines. Cancer Lett. 2005, 230, 134-140. [CrossRef]

24. Nataro, J.P.; Baldini, M.M.; Kaper, J.B.; Black, R.E.; Bravo, N.; Levine, M.M. Detection of an adherence factor of enteropathogenic Escherichia coli with a DNA probe. J. Infect. Dis. 1985, 152, 560-565. [CrossRef] [PubMed]

25. Boyer, H.W.; Roulland-Dussoix, D. A complementation analysis of the restriction and modification of DNA in Escherichia coli. J Molbiol 1969, 41, 459-472. [CrossRef] 
26. Frimodt-Møller, J.; Charbon, G.; Krogfelt, K.A.; Løbner-Olesen, A. Control regions for chromosome replication are conserved with respect to sequence and location among Escherichia coli strains. Front. Microbiol. 2015, 6, 1011. [CrossRef] [PubMed]

27. Frimodt-Møller, J.; Charbon, G.; Krogfelt, K.A.; Løbner-Olesen, A. DNA replication control is linked to genomic positioning of control regions in Escherichia coli. PLoS Genet. 2016, 12, e1006286. [CrossRef] [PubMed]

28. Kenyon, C.J.; Walker, G.C. DNA-damaging agents stimulate gene expression at specific loci in Escherichia coli. Proc. Natl. Acad. Sci. USA 1980, 77, 2819-2823. [CrossRef] [PubMed]

29. Baba, T.; Ara, T.; Hasegawa, M.; Takai, Y.; Okumura, Y.; Baba, M.; Datsenko, K.A.; Tomita, M.; Wanner, B.L.; Mori, H. Construction of Escherichia coli K-12 in-frame, single-gene knockout mutants: The Keio collection. Mol. Syst. Biol. 2006, 2, 2006.0008. [CrossRef] [PubMed]

30. Miller, J.H. Experiments in Molecular Genetics; Cold Spring Harbor Laboratory: Cold Spring Harbor, NY, USA, 1972 ; pp. 352-355.

31. Clinical and Laboratory Standards Institute. Performance Standards for Antimicrobial Susceptibility Testing; Twenty-Seventh Informational Supplement; CLSI Document M100-S27; Clinical and Laboratory Standards Institute: Wayne, PA, USA, 2017.

32. Scaletsky, I.C.; Silva, M.L.; Trabulsi, L.R. Distinctive patterns of adherence of enteropathogenic Escherichia coli to HeLa cells. Infect. Immun. 1984, 45, 534-536. [CrossRef] [PubMed]

33. Mosmann, T. Rapid colorimetric assay for cellular growth and survival: Application to proliferation and cytotoxicity assays. J. Immunol. Methods 1983, 65, 55-63. [CrossRef]

34. Silva, T.F.; Filho, J.R.N.C.; Fonsêca, M.M.L.B.; Santos, N.M.; Silva, A.C.B.; Zagmignan, A.; Abreu, A.G.; Silva, A.P.S.; Lima, V.L.M.; Silva, N.H.; et al. Products Derived from Buchenavia tetraphylla Leaves Have In Vitro Antioxidant Activity and Protect Tenebrio molitor Larvae against Escherichia coli-Induced Injury. Pharmaceuticals 2020, 13, 46. [CrossRef] [PubMed]

35. Harrington, S.M.; Sheikh, J.; Henderson, I.R.; Ruiz-Perez, F.; Cohen, P.S.; Nataro, J.P. The Pic protease of enteroaggregative Escherichia coli promotes intestinal colonization and growth in the presence of mucin. Infect. Immun. 2009, 77, 2465-2473. [CrossRef]

36. Abreu, A.G.; Abe, C.M.; Nunes, K.O.; Moraes, C.T.; Chavez-Duenas, L.; Navarro-Garcia, F.; Elias, W.P. The serine protease Pic as a virulence factor of atypical enteropathogenic Escherichia coli. Gut Microbes. 2016, 7, 115-125. [CrossRef]

37. Goodman, M.F.; Woodgate, R. Translesion DNA polymerases. Cold Spring Harb. Perspect. Biol. 2013, 5, a010363. [CrossRef]

38. Ordonez, H.; Uson, M.L.; Shuman, S. Characterization of three mycobacterial DinB (DNA polymerase IV) paralogs highlights DinB2 as naturally adept at ribonucleotide incorporation. Nucleic Acids Res. 2014, 42, 11056-11070. [CrossRef] [PubMed]

39. Johnson, R.E.; Prakash, S.; Prakash, L. The human DINB1 gene encodes the DNA polymerase Pol日. Proc. Natl. Acad. Sci. USA 2000, 97, 3838-3843. [CrossRef] [PubMed]

40. Sutton, M.D.; Smith, B.T.; Godoy, V.G.; Walker, G.C. The SOS response: Recent insights into umuDC-dependent mutagenesis and DNA damage tolerance. Annu. Rev. Genet. 2000, 34. [CrossRef]

41. Nazir, A.; Harinarayanan, R. Inactivation of cell division protein FtsZ by SulA makes Lon indispensable for the viability of a ppGpp0 strain of Escherichia coli. J. Bacteriol. 2016, 198, 688-700. [CrossRef]

42. Prabuseenivasan, S.; Jayakumar, M.; Ignacimuthu, S. In vitro antibacterial activity of some plant essential oils. BMC Complement. Altern. Med. 2006, 6, 39. [CrossRef] [PubMed]

43. Li, X.; Sheng, J.; Huang, G.; Ma, R.; Yin, F.; Song, D.; Ma, S. Design, synthesis and antibacterial activity of cinnamaldehyde derivatives as inhibitors of the bacterial cell division protein FtsZ. Eur. J. Med. Chem. 2015, 97, 32-41. [CrossRef]

44. Yuan, W.; Yuk, H.G. Effect of sublethal thymol, carvacrol and trans-cinnamaldehyde adaptation on virulence properties of Escherichia coli O157:H7. Appl. Environ. Microbiol. 2019, 85, e00271-19. [CrossRef] [PubMed]

45. Malheiro, J.F.; Maillard, J.Y.; Borges, F.; Simões, M. Evaluation of cinnamaldehyde and cinnamic acid derivatives in microbial growth control. Int. Biodeter. Biodegrad. 2019, 141, 71-78. [CrossRef]

46. Firmino, D.F.; Cavalcante, T.T.; Gomes, G.A.; Firmino, N.; Rosa, L.D.; de Carvalho, M.G.; Catunda, F.E., Jr. Antibacterial anAntibiofilm Activities of Cinnamomum Sp. Essential Oil and Cinnamaldehyde: Antimicrobial Activities. Sci. World J. 2018, 2018, 7405736. [CrossRef]

47. Field, D.; Baghou, I.; Rea, M.; Gardiner, G.; Ross, R.; Hill, C. Nisin in Combination with Cinnamaldehyde and EDTA to Control Growth of Escherichia coli Strains of Swine Origin. Antibiotics 2017, 6, 35. [CrossRef] [PubMed] 